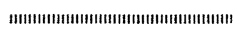

轱訜

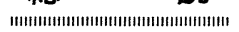

\title{
ファッション テクノロジィの展開“
}

1. はじめに

ファッション テクノロジィは,筆者らのグループ主)が 勝手に作った言葉で, ファッションに関する「情報の選 択 $\rightarrow$ 分析 $\rightarrow$ 予測 $\rightarrow$ 商品化についての多様なソフトウェ ア技術」を意味している，てのような技術の必要性, 社 会的な存在理由, 基本的な考え方などについてはすでに 述べだ”. 従って, こてでは, レデイスファッションの 情報分析およびそれによる次シーズンへの予測につい て，てれまでに得た結果をまとめて紹介したい，なお， ファッション情報についてあてはまると思われる情報の 選択と分析の必要性について，以下の文章を引用してお $\langle 2)$.

「情報がありすぎるという事は，情報の山の中から， 欲しい情報を選び出さなければならないという事を意味
会員川崎 健太 郎*

している．欲しい情報を選び出さなければならないとい う状態は, 結局は情報が足りないという状態と同じ事で ある」²。

\section{2. 情報の分析と予測の方法}

てれまですでにファッション情報の分析と次シーズン の予測は, ヤング レディス タウンウェアを対象とし て, 今秋 (1978年) のルック予測を昨年 11 月に，来春 (1979年) のルック予測を今年 4 月に行っている．その 過程で分析, 予測の方法, プロセスの定型化も進み，そ れなりにまとまったので，図示すれば，眓1のようにな る. こてでは, いくつかのルートを, 大まかに,

(1) ルックイメージの分析と予測

(2) 服装の出現頻度調査と予測

(3) 予測結果のまとめ

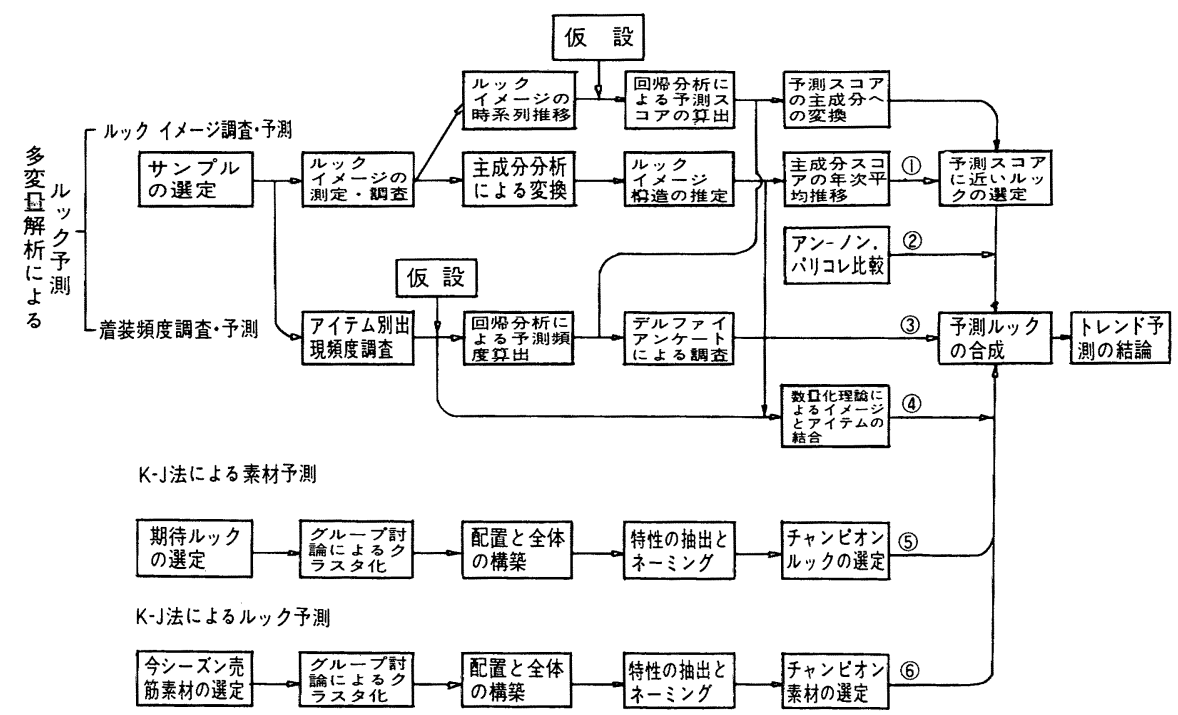

図1 ファッション予測の方法

*Development of "Fashion Technology".

** K. Kawasaki, Member. 蝶理 瀻維マーケティング部長（工博） 
に分けて概要を述べる.

いずれにせよ, 基本的には, データ解析では, 過去数 シーズンのデータの時系列推移から, ある仮説のあとに 次シーズンへの外捜を試みるととであり，他方では直観 的, 感覚的な予測をグループ討論の中でまとめ, 最終的 にいろいろなルートからの推論を総合的に判定すること からなる。

\section{3. 調查の準備}

ルック予測のための調査サンプルは，おしゃれ派のヤ ングレディに圧倒的に多く購読され，かつ，先行性の あるファッション情報誌として知名度の高い3゙アンア ン, ノンノ誌から, 該当するルック写真をランダムに選 んだ.

すなわち，乙れらの雑誌から，乙の調査の目的とす る，19才〜23才ぐらいのヤングレディを主な対象とす るタウンウェアのルック写真を, 最近 3 年間について, それぞれ予測シーズンに合わせて，概当する写真を選ぶ （予測の目標をタウンウェアとしたので，ラウンジウ ェア，イブニングドレス，フォーマルウェアなどを除 き, また盛夏の水着, リゾートウェア, 真冬のフアー コートなども除いている). 結局, '78 秋冬の予測資料之 して，1975年～77年 8～12月号より 284 点（該当する揭 載誌のルック写真の約 $1 / 2$ を, 資料として条件に合う写 真の中から無作為抽出), '79 春夏の予测資料として, 1967年〜 78年 $2 \sim 5$ 月号より 127 点（該当する揭載誌の ルック写真の約1/4) をそれぞれ選び, ’78 秋冬のための 分析作業は昨年11月， '79 春夏のための分析作業は今年 4 月に実施した（結果はアンノン $\mathrm{S} / \mathrm{S}$ または $\mathrm{F} / \mathrm{W}$ と略 記する).

他に1975～77年の毎年秋に，翌年の春の装いのために 発表されるパリのプレタ ポルテ コレクションのスライ ド82枚を選び， '78 春夏予測の資料とした（結果はパリ コレ $\mathrm{S} / \mathrm{S}$ と略記する).

ルックイメージの調査については, 合繊メ一カ, テ キスタイルミル, 商社, アパレルメーカ, ストア, 各 社の商品企画スタッフおよびアトリエデザイナなどの 専門家15名をパネラとし，予め用意したルックイメー ジ調査票（表 1 ）を用いて行った. 表 1 の20のイメージ 表現は，いずれあファッション情報誌でよく見られる形 容語の中から，意味がわかりやすい用語を，着こなしの イメージを万遍なく網羅するに必要な最少限だけ選んで いる. パネラは，サンプル ルックのスライドを見て， 感じたままに記入（ここでは 3 段階評定）する，ての調 査法はセマンティックディフォレンシャル法(SD法, 意味分析法）と呼ばれている。このようにして得られた 各パネラの評点を, 各ルック サンプル 1 枚ごとに 20 個 のイメージ表現について平均し，以降の分析を進める.
表 1 ルックイメージの調査票

\begin{tabular}{|c|c|c|c|c|}
\hline & & である & 0 & でない \\
\hline 1 & ドレッシィな & 1 & 2 & 3 \\
\hline 2 & 懐古的な & 1 & 2 & 3 \\
\hline 3 & フォーマルな & 1 & 2 & 3 \\
\hline 4 & マニッシュな & 1 & 2 & 3 \\
\hline 5 & はなやかな & 1 & 2 & 3 \\
\hline 6 & 個性的な & 1 & 2 & 3 \\
\hline 7 & カジュアルな & 1 & 2 & 3 \\
\hline 8 & デコラティブな & 1 & 2 & 3 \\
\hline 9 & フォークロア的な & 1 & 2 & 3 \\
\hline 10 & 大人っぼい & 1 & 2 & 3 \\
\hline 11 & ナチュラルな & 1 & 2 & 3 \\
\hline 12 & かわいらしい & 1 & 2 & 3 \\
\hline 13 & ベーシックな & 1 & 2 & 3 \\
\hline 14 & フェミニンな & 1 & 2 & 3 \\
\hline 15 & 若々しい & 1 & 2 & 3 \\
\hline 16 & 優雅な & 1 & 2 & 3 \\
\hline 17 & ロマンチックな & 1 & 2 & 3 \\
\hline 18 & シンプルな & 1 & 2 & 3 \\
\hline 19 & さわやかな & 1 & 2 & 3 \\
\hline 20 & スポーティな & 1 & 2 & 3 \\
\hline
\end{tabular}

服装（着こなし）の出現頻度調査も，同じサンプルに ついて別に用意したチェックリストによって行ってい る. この調査はスタイル, 服種, 色柄, 素材 (イメージ) などをアイテム別に分類し，その出現頻度を集計，推移 を検討することを目的としているので，項目別に $2 \sim 3$ 名の専門家がルック サンプルを見ながら合議判定して 分類し頻度を調査した。

\section{4. 調查結果}

\section{1 ルックイメージの分析と予測}

ファッションは消費者に受け入れられた着てなし, 服 装であることは確かであるから，着こなしが，消費者に どのように受け止められているか，つまりルックをイメ ージに変換し，さらに時系列的なルックの移り変りをイ メージの変化として捉えることがこの方法の進め方であ る.

\section{A.ルックイメージの構造}

3.で述べたように SD 法で調查したルックイメー ジの分析には多変量解析法の中の主成分分析法を用い た. 多変量解析とは, 数多くの要因 (変量)によって起 る現象を，できるだけ情報のロスを防ぎながら，少数の 要因で説明するための数学的な方法である. 因子分析， 回帰分析，判別分析，主成分分析など，いろいろな手法 があるが，分析法の詳細は他書 ${ }^{4)}$ 亿譲る.なお，ここで 主成分分析法を用いたのは，偶々この方法がわれわれの 目的に適しており，慣れていたからにすぎない，主成分 分析法によれば，数多くの変量（ここではドレッシィな ……から始まりスポーティな……までの20個のスコア） $x_{1}, x_{2}, \cdots x_{20}$ によって表わされるルックイメージを, 乙れらの変量 $x_{1}, x_{2}, \cdots x_{20}$ の重み付きの総合特性値 $z_{1}, z_{2}, \cdots$ 一表わすととができる.すなわち,

$$
\begin{aligned}
z_{i} & =l_{i 1} x_{1}+l_{i 2} x_{2}+\cdots l_{i 20} x_{20} \\
& =\sum_{j=1}^{20} l_{i j} x_{j} \quad \cdots \cdots \cdots \ldots \ldots \ldots \ldots \ldots \ldots \ldots \ldots \ldots
\end{aligned}
$$




$$
\begin{aligned}
& (i=1,2, \cdots m, m<20 \\
& \text { ここでは } m=3 \text { まで })
\end{aligned}
$$

$$
\sum_{j=1}^{20} l_{i j}{ }^{2}=1
$$

\begin{tabular}{|c|c|c|c|}
\hline $\begin{array}{l}\text { 寄 与 率 } \\
\text { 累積寄与率 }\end{array}$ & $\begin{array}{l}z_{1} \\
0.377 \\
0.377 \\
\end{array}$ & $\begin{array}{c}z_{2} \\
0.229 \\
0.606\end{array}$ & $\begin{array}{c}z_{3} \\
0.129 \\
0.736 \\
\end{array}$ \\
\hline 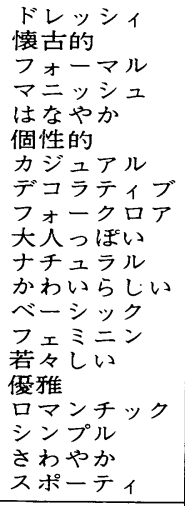 & $\begin{array}{r}0.32721 \\
0.21507 \\
0.26335 \\
-0.19405 \\
0.27339 \\
-0.03210 \\
-0.31987 \\
0.21501 \\
0.08701 \\
0.13148 \\
-0.17675 \\
0.08499 \\
-0.02684 \\
0.33145 \\
-0.13052 \\
0.32129 \\
0.31350 \\
-0.09186 \\
-0.08770 \\
-0.32677 \\
\end{array}$ & $\begin{array}{r}0.15107 \\
-0.25402 \\
0.17531 \\
-0.16359 \\
-0.18821 \\
-0.33606 \\
-0.14737 \\
-0.28921 \\
-0.33287 \\
0.23646 \\
0.10095 \\
-0.18424 \\
0.40483 \\
0.08054 \\
-0.22225 \\
0.05818 \\
-0.08500 \\
0.35971 \\
0.15881 \\
-0.07485\end{array}$ & $\begin{array}{r}-0.00365 \\
-0.04022 \\
-0.13648 \\
-0.28221 \\
-0.03024 \\
-0.24403 \\
-0.04238 \\
0.00341 \\
0.09058 \\
-0.40061 \\
0.04650 \\
0.50532 \\
0.16460 \\
0.09571 \\
0.41601 \\
-0.07431 \\
0.20219 \\
0.19271 \\
0.33795 \\
-0.06750 \\
\end{array}$ \\
\hline 予 測 值 & -0.559 & 1.460 & -0.448 \\
\hline
\end{tabular}

表 2 ルック イメージの主成分スコアと'79年の予測

表 2 は, アンノンの S/S ルック サンプルについて得 られた係数 $l_{i j}$ のマトリックス（個有べクトル）であ る. 各主成分 $\left(z_{1}, z_{2}, z_{3}\right)$ について, 係数 $l_{i j}$ の大小 は，それぞれのイメージ表現の寄与の大小を示してい る. また寄与率は，それぞれの主成分スコアがトータル のルック イメージの内容をどの 程度説明しているかを 示す指数であり, ての表から, 第 1 主成分によってト一

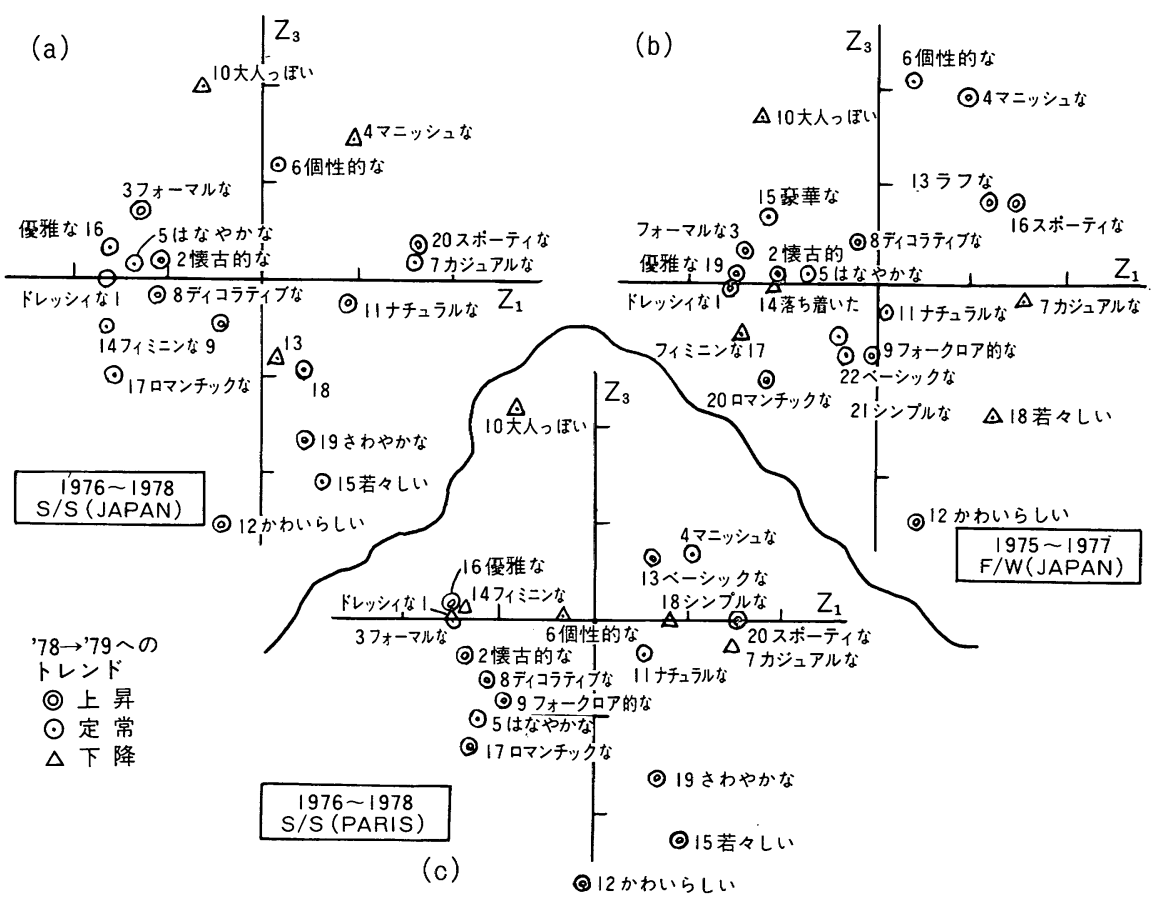

図2 ルックイメージの構造 $\left(z_{1} \sim z_{3}\right.$ のみ $)$ あので, 明らかにルックイメージは

$$
\begin{aligned}
& z_{1} ; \text { スポーティ〜ドレッシ } \\
& z_{2} ; \text { 個性的〜ベーシック } \\
& z_{3} \text {; 大人っぼい〜かわいらしい }
\end{aligned}
$$
するととが妥当であるともいえよう.

B. 仮説（ファッションは回帰する?）

(b)

タル イメージの約 38\%が，第 3 主成分まで（累積寄与 率）でイメージに関する情報量の約 $74 \%$ が説明されるこ とがわかる. 図2（a）は表 2 の係数をグラフに表示した

の3 軸の空間で構成されているととがわかる. 図 2(b) は昨年秋に，アンアン,ノンノをサンプルとした，78秋 /冬のルック予測で, 図 2(c)は今年春に(1)のアンア ン,ノンノ調査と同時に行ったパリプレタ ポルテコレ クションに関する'79春/夏のルック予測で得られた結 果を示す. てれらのグラフを比較すれば, 驚くほどルッ クイメージの構造が 良く似ていることがわかる，着用 のシーズンが異なり, 着用の対象が日本のヤング, パリ のミッシィと違っても，また一方は一般消費者を対象と するファッション誌の, 他方はアパレルメーカ, ス卜 アのバイヤ, デザイナを対象とするショーというように サンプルの性格がまったく違っても, 着てなしの心理的 な受けとめ方，ルックイメージの構造はほとんど变っ ていないととが確かめられた。しかるが故にてそ、ルッ クイメージをファッションの分析, 予測の手がかりと

ルックイメージの予測にしても，服装アイテムの予 測にしても，とてでやろうとしているとは（分析作業の 
労力, サンプル データ収集量の制約から), 過去 3 か年 の時系列データから, 次年度へのトレンドを導くことで あるから, 何らかの仮定が必要となる.

そてで「ファッションは回帰する」という一つの仮説 を提起しよう.ただし，ててでは，一部に話題となって いるような 4 年あるいは 8 年ごとに綝返すといった一定 周期を仮定していない5).

「ファッションは回帰する」という仮説は言い換えれ ば, ルックイメージ, 服装アイテム, 着装, 着てなし の頻度, 商品の普及率などで数量化されたファッション アイテムについて,「多いむの, 高い普及レベルにある あのは減少あるいは低い方へ, 少ないあの, 低いレベル のあのは多くなり, 高い方向へ伸びる」傾向があるとい うことである.

ファッション（現象あるいは商品）に対する定説はな いが, 「ある期間, ある範囲の人達に受け入れられた衣 服の移り変り」 ${ }^{6)}$ を意味しているととが常識として是認 されるならば, ファッションに対応する数量インデック スは, 何らかの意味で(普及率, 着装頻度などの量的レ ベルに関連する指標と，回恋化の数量指標としての意及 率, 着装頻度などの伸び率（例えば前シーズン対比）で 表現できのではあるまいか. どのような数字を指標とし て使うのが妥当か（例えば普及率では対象とする商品了 イテムの潜在需要層の $5 \%$ 以上とか, 前シーズン対比の 着装頻度伸び率は30\%以上とか）は，商品アイテムによ って，また市場構造によって異なると考えられるが，今 後のデータの蓄積によっておのずから定まるであろう.

とてでは，前記の仮説が本質的にてのファッションの 定義に深い関わりを持つてとを指摘しておきたいまま た，誤解をさける意味からこてで触れなければならない のは,「ファッションは回帰する」ということは，1940 年代ルックといわれるように過去のスタイルと同じスタ イルが，常に綝返されるという意味ではない，以下の デー夕解析法法が持つ宿命的な制約でああるが，イメー ジあるいは商品アイテムとカテゴリ、に要約し，平均化 した数量, しかむ 1 次元の数量の変化において, 高 $\rightarrow$ 低，低 高と繰返されるという意味である．現実の服装 では, 服種, シルエット, ディテール, 素材, 色柄の複 雑な組合わせと各要素における無限のバラエティがある 訳で, ファッションが意味するもう一つの重要なフォク タである斬新さ，意外性は，てのデー夕処理の中ではい わば誤差として丸め込まれる結果となる。

図3は，アンノン S/S のルック サンプルについて測 定されたイメージスコアから豆かれた，ルックイメー ジの過去 3 年間の推移を示す. すなわち, 横軸の’76〜'78 年にわたる各年次について, 各年次約 40 枚のルック写真

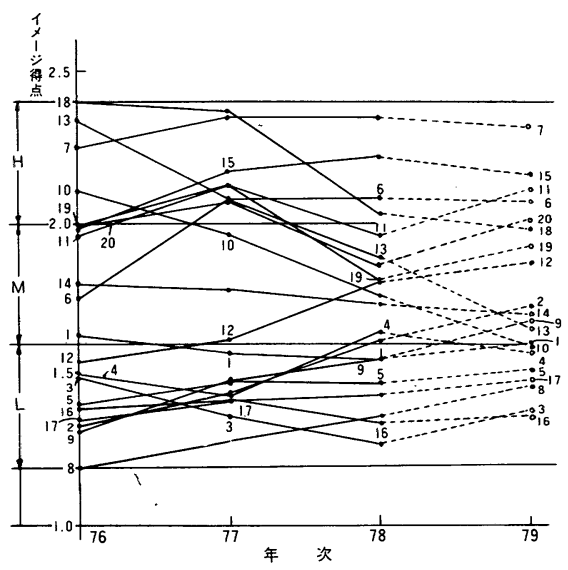

図3 ルックイメージの推移と予測 (アンノン S/S ) (図中の数字は表 1 のルックイメージ番号)

表 3 推移の型と予測式

\begin{tabular}{|c|c|c|c|c|c|}
\hline 型 & \multicolumn{2}{|c|}{ 単 調 $(L)$} & \multicolumn{3}{|c|}{ 周 期 $(P)$} \\
\hline \multirow{2}{*}{$H$} & & & & & 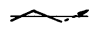 \\
\hline & $Y$ & $Y_{0}$ & $Y \pm R$ & $Y_{0} \pm R$ & $Y \pm R$ \\
\hline \multirow{2}{*}{$M$} & & & & & $\ldots$ \\
\hline & $Y$ & $Y$ & $Y \pm R$ & $Y \pm R$ & $Y \pm R$ \\
\hline \multirow{2}{*}{$L$} & & & 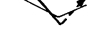 & & $\ldots$ \\
\hline & $Y_{0}$ & $Y$ & $Y_{0} \pm R$ & $Y \pm R$ & $Y \pm R$ \\
\hline \multicolumn{6}{|c|}{$\begin{array}{ll}Y=\alpha+\beta t & \text { 回帰推定値 } \\
R & \text { 残差 } \\
Y & \text {, }\end{array}$} \\
\hline
\end{tabular}

について，1.ドレッシィな，‥20. スポーティなの各 イメージスコア別に平均值を求め, その推移を折線で プロットしている．との 3 点の時系列スコアから， 79 春夏のイメージ予測スコアを, 次の表 3 により最も常識 的かつ単純な方法で算出する.

すなわち，上記の仮説に従って，イメージスコアレ ベルは, 過去 3 年の最大, 最小值の範囲をほぼ 3 等分し, $H, M, L$ とし, 推移曲線のタイプを単調型と, 周期型 にわける．各タイプいずれあ基本的に単回帰直線式

$$
\begin{aligned}
& Y=\alpha+\beta t \\
& t \text {; 年次 } \\
& \alpha, \beta \text {; 係数 } \\
& Y \text {; 回帰推定値 }
\end{aligned}
$$

により 4 年目に当る1979年の予測值 $Y$ を求める. この場 合, 周期型のイメージについては, さらに周期変動がオ 一バ ラップすると考えて, 回帰残差 $R$ $Y$ に加減して 補正する。

ただし， 


$$
R^{2}=(1 / 3) \sum_{i=1}^{3}\left(y_{i}-Y_{i}\right)^{2}
$$

\section{$\left\{y_{i i} ;\right.$ 各年次の実測値 \\ $\left\{Y_{i} ;\right.$ 各年次の推定値}

また，上記の仮説に従い，Hレベルのスコアは $L$ レベ ルへ，LレベルのスコアはHレベルへと推移する傾向が あるから，例えば表 3 左下欄のようにLレベルでさらに 下降傾向を示しているスコアについては，次年度は下降 公配と同じ勾配で反転上昇すると考える. この場合簡単 な計算によって，予測値は昨年次の推定值 $Y_{0}$ (ここで は’77 年度) 汇等しくなる.

図3に拈ける79予測值は, てのようにして得られた スコアである．との予測スコア $x_{1^{\prime}}, x_{2}^{\prime} \cdots x_{20}{ }^{\prime}$ を前 (1)式に代入すれば（数学的にはこの操作に疑問はある が), とあかく’79年に予想されるルックのイメージか ら，期待ルックの主成分スコア $\left(z_{1}{ }^{\prime}, z_{2}{ }^{\prime}, z_{3}{ }^{\prime}\right)$ を導く ことができる.

C. トレンドの予測（'79はモア ドレッシィへ?）

図2のルックイメージ構造によってトレンドの予測 を試みよう。

図 4 は, アンノン サンブルのルック イメージ空間に

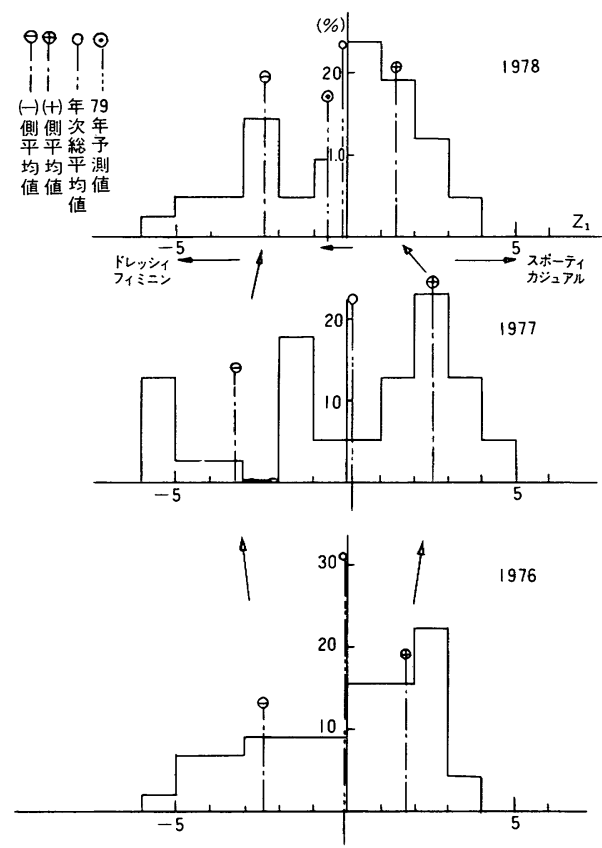

図4 ルックイメージ主成分得点 $\left(z_{1}\right)$ の分布 (アンノン $\mathrm{S} / \mathrm{S}$ )

おける主成分得点 $\left(z_{1}\right)$ の散布をヒストグラムで示した あのである.すなおち, 年次別に, 横軸の $z_{1}$ 主成分ス コアの区画内に散布するサンプルの頻度を綐軸にプロッ トしたもので, 図中にそれぞれ，各年次のサンプル分布 の総平均值, $(+)$ スポーティサイドの平均値, (一)ド
レッシィサイドの平均値を，さらに78 年度について は, 前節で得られた'79年予測值（総平均值に相当）を 図示した。時系列的な推移を辿れば，分布の総平均值は ほとんど中心軸から動いていないが，ファッションの二 極化といわれるように，(+)サイド，（一)サイドに分け て動きを見ると、 76 年から 77 年にかけて、ルックイ メージは, ドレッシィ, スポーティの両極に分化し, '78年では, 全体の重心をややドレッシィサイドに移し ながら, 再び収斂の動きを示している（このような推移 は, ジーンズ ボトムにTーシ+ツ ルックといったいわ ゆるスポーティカジュアルー辺倒からジョーゼットの ドレス ブラウスが，ファッションの主流となった'77 年, さらにその展開が続いている 78 年と, マーケット の動きを反映している).さらに79年の予測ではさらに 全体のイメージはドレッシィサイドへ移るとともに， 両極へ抎散するように思われる．同じような操作之分析 を, パリのプレタ ポルテ コレクションについても行 い, 主成分スコア分布の平均推移を比較したのが，図 5 である、スコアレベルの高低はあるが，時系列的な推 䔟はまったく良く似ているととがわかる.

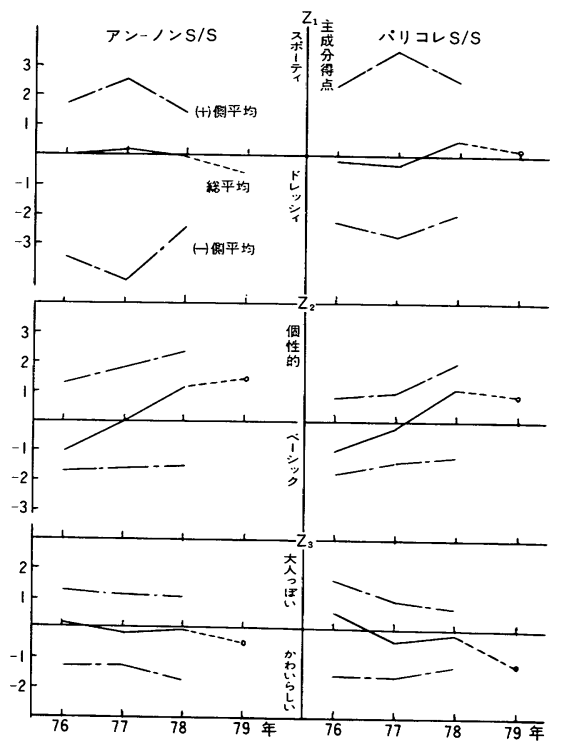

図 5 ルックイメージ主成分スコア $z_{i}$ 平均值の推移

パリのプレタ ポルテ コレクションが, シーズンの半 年前に，世界の一流デザイナが，ジャ一ナリスト，アパ レルメーカ，ストアに対して，しかもヤングよりあミ ッシィを対象として製作した作品を発表するのに対し， アンアン, ノンノはシーズンに1〜2 加先きがけて， しかあ若い一般女性を対象にして編集されたファッショ ン誌である. このように，サンプルルックの意図, 内 容に大きなへだたりがあるにあかかわらず，ルック イ メージにおき代え時系列で見れば，良く似た傾向を示す 


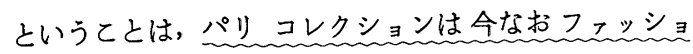
ンの原点であるてとを改めて示すすのではなかろうか.

\section{2 服装（着こなし）の頻度調査と予測}

ファッションの多様化，個性化といわれているよう に，ほとんど無限のバリエーションを持つ多変量から成 る服装から，主な要因を選び，その各々の出現頻度を一 次元のデータとして, 時系列的な推移を辿る. さらに上 記の仮説に基づいて，4.1 と同じ手順で '79 年の予測頻 度を推定する。

A. 調査票の作成(アイテムの分類, 要約がポイント) あらゆる角度から検討して, 必要にして充分な最少限 のアイテムとカテごリィを選び, かつ調査時点, パネラ が変ってあ分類がばらつかないように普遍的かつ妥当な 分類基準を設定する必要がある. この調査では，2〜3 名の判定者の合議によってルックサンプルを各アイテ ムのいずれかに判定するとととし，例えば，丈け長さに ついては滕丈けを基準として上，下に分けるなど適宜判 断基準を設けて判定している.ルック サンプルは、 メージ調査と同じサンプルを用いた。

表 4 は，乙の調査に使った調查票である．各アイテム とあ, 独立したカテゴリ、に細分化され，調査の際必ず 各コラム之も，いずれかにチェックされるように設計し た.

なお，カテゴリィへの細分化は，細かすぎれば，分類 判定に手間取るとと屯に，データとしてまとめる段階 で，他のカテゴリィに対しほとんど無視できるほどの小
さな頻度となり，結局まるめる必要が起きるままた，あ まりにラフすぎれば, 意味のない一般的, 抽象的な推論 となって役立たない．さらに，あるカテゴリィにのみ数 字が偏ると，カテゴリ1の細分化が万遍なく行われたか どうかに疑問が残る。これらの事情から，1つのアイテ ムは結局 3〜8個のカテゴリ、に細分化するのが望まし い.

B. 服装の頻度推移と予測（'79 のホット ナンバ ア イテムを探る)

図6は，アイテムでとに出現頻度の推移をプロット し，かつ， 4.1 と同様にして'79 S/S の頻度を予測した 結果を示す。なお, 出現頻度レベルについては, 普通過 去 3 か年における最大值と最小值の差 (レンジ) を 3 等 分しているが, アイテム〜カテゴリィによってはベーシ ックアイテムとして多少の上下はあってあ常に高い普 及レベルにあるものあある．とのような普及レベルの水 蕉は今後のデータの積み重ねととあに明らかになるであ ろうが，乙の図でも，シルエットにおけるストレート

ラインと，フィットに関するノーマルフィットは，本 来高いレベルにあるものとしてその最低レベルを $50 \%$ 之 し，100〜50\%のレンジを 3 等分していることを付記し ておく（図７はとのととを示す例証として，過去３か年 にわたる秋冬物の頻度調査と, 春夏物の頻度調査結果を 半年ずらせて重㸚合わせた結果を示す，ての図からべー シック アイテムのレベルが他のアイテムと区別される ことが予想できる).

表 4 服装調査票

質問 1 ：シルエット

\begin{tabular}{|c|c|c|c|c|}
\hline 1 & 2 & 3 & 4 & 5 \\
\hline 5 & $\square$ & & \\
& & & \\
\hline
\end{tabular}

質問 3 : 丈け長さ

\begin{tabular}{|l|c|c|c|}
\hline & ミニ膝上 & ノーマル膝丈 & ロング膝下 \\
\hline ドレス & 1 & 2 & 3 \\
\hline スカート & 1 & 2 & 3 \\
\hline パンツ & 1 & 2 & 3 \\
8
\end{tabular}

質問 5 : 服種

\begin{tabular}{|c|c|c|c|c|c|c|c|c|c|}
\hline \multicolumn{2}{|c|}{ アウ夕 } & 1 スーツ & 2 ス゚ーツ & 3 ソフト & 4 ドレス & 5 アンサンブル & $6 \begin{array}{c}\text { 組み合せ } \\
\text { スカート }\end{array}$ & 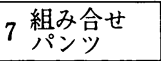 & \multirow{2}{*}{11} \\
\hline \multirow{3}{*}{$\begin{array}{l}\text { 組 } \\
\text { み } \\
\text { 合 } \\
\text { せ }\end{array}$} & ボ $ト$ ム & $1 \begin{array}{l}\text { ストレート } \\
\text { スカート }\end{array}$ & $2 \begin{array}{l}\text { フレーヤ } \\
\text { スカート }\end{array}$ & \begin{tabular}{|c|}
3 \\
プリーツ \\
スカート
\end{tabular} & $4 \begin{array}{l}\text { ギャザ } \\
\text { スカート }\end{array}$ & 5 杀 & \begin{tabular}{|c|} 
ストレート \\
ベル ボトム \\
パンツ
\end{tabular} & $7 \begin{array}{l}\text { ジーンズ } \\
\text { パンッ }\end{array}$ & \\
\hline & トップ(内) & 1 シャツ & 2 ブラウス & 3 T. シャツ & 4 ベスト & 5 ジャケット & 6 ブレザ & $7 \begin{array}{l}\text { セータ } \\
\text { カーディガン }\end{array}$ & 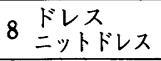 \\
\hline & トップ(外) & 1 シャツ & 2 ブラウス & 3 T- シャツ & 4 ベスト & 5 ジャケット & 6 ブレザ & $7 \begin{array}{l}\text { セータ } \\
\text { カーディガン }\end{array}$ & $8 \begin{array}{l}\text { ドレス } \\
\text { ニットドレス }\end{array}$ \\
\hline
\end{tabular}

質問 6 : カラー (省略)

質問 7 : 素材 (イメージ) (省略)

\begin{tabular}{|c|c|c|}
\hline 1 & 2 & 3 \\
\hline $\begin{array}{l}\text { ビッグ } \\
\text { (ルーズ) }\end{array}$ & ノーマル & スリム \\
\hline
\end{tabular}

質問 4 ：配色

\begin{tabular}{|c|c|c|}
\hline 1 & 2 & 3 \\
\hline 同 色 & 類 似 色 & 対 比 色 \\
\hline
\end{tabular}




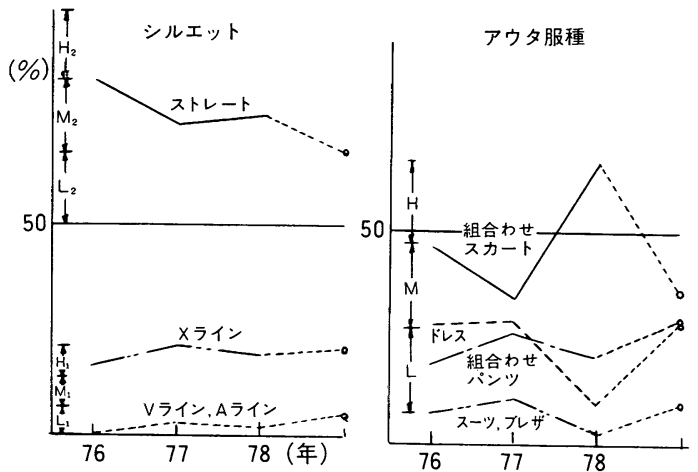

色 相
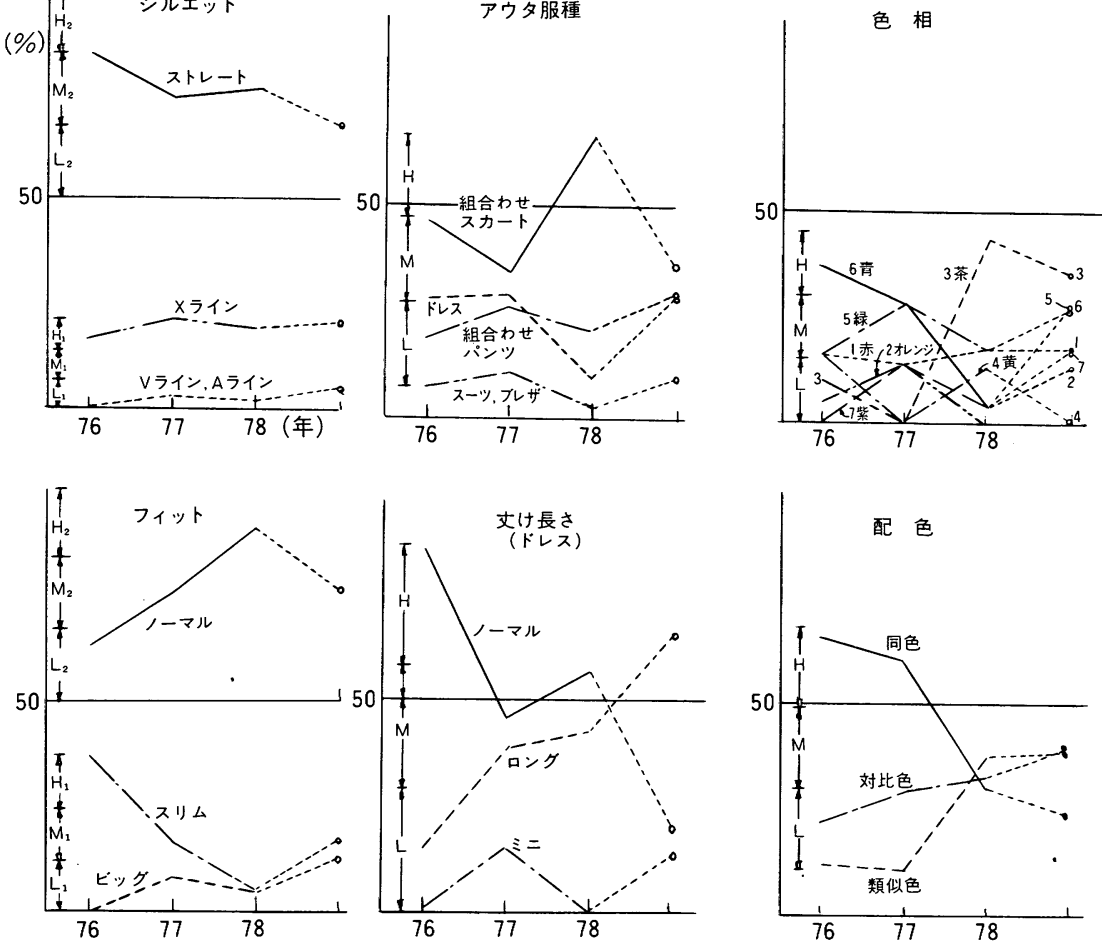

図6 服装アイテムの頻度推移と予测（アンノン $\mathrm{S} / \mathrm{S}$ )

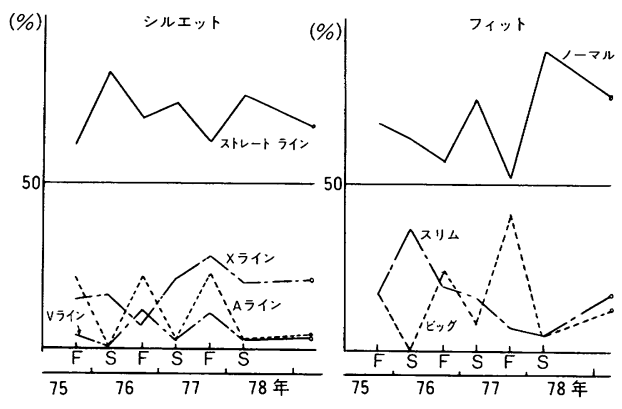

図 7 服装アイテム頻度推移（アンノン $\mathrm{S} / \mathrm{S}$ と $\mathrm{F} / \mathrm{W}$ の合成)

かくして，服装の主なアイテムについて，その当否は別 として，大まかな分類ではあるが，半ば定量的にどの程 度の頻度で, ぞの程度の伸び率で推移するかを予測する ことができた.

\section{3 予測結果の要約}

これまでの（ルックイメージおよび服装の頻度に関 する）データによる多変量解析のほか，K-J 法による素 材，ルックイメージの予測など，多面的なアプローチ を試みさらに結果をしぼり込んだ.

A. データ解析とデルファイ予測（コンピュータ予測 とカンピュータ予测)

デルファイ法と呼ばれる未来予測の方法は，ゴードン
とヘルマーによって1964年に開発された一種のアンケー 卜手法7)で，特に未来技術（の実現年次）について専門 家の意見を周到かつ組織的に引出すように工夫されてい る. ここではデータ解析による結果を15名のメンバに提 示説明するととあに，乙の結果を参照しながら，しかも それにこだわることなく次年度への各項目のトレンド (上昇または下降)，および期待されるスコアレベル(イ メージ スコアおよび出現頻度）についてアンケートし， 得られた回答を平均した.

表 5 はこれらの結果の一部を示す.一般に回答は下降 傾向，および低いスコア レベルを記入することに抵抗 があったようで, いずれのスコアあデータ予測值に比 べ, 高い回答予測値を示した. そこで原回答值とデータ 予測值との 総平均值（例えばルックイメージについて は 1 から 20 までのイメージ アイテム スコアの総平均 值) の差を原回答値加ら減らして修正値とした。ほとん どの項目についてトレンドのアンケート結果はデータ解 析の結果と一致している.なお両者の一致度を項目数に よって示せば92項目について

\begin{tabular}{|c|c|}
\hline (まったく一致 & $55^{\text {項目 }}$ \\
\hline \{いずれであない & 35 \\
\hline （まったく反対 & 2 \\
\hline
\end{tabular}

であった。 
表 5 データ予測とデルファイ予測（の一部）

\begin{tabular}{|c|c|c|c|c|c|c|c|c|c|c|c|}
\hline & & \multicolumn{3}{|c|}{ 実 測 值 } & \multirow{2}{*}{ 推移 } & \multirow{2}{*}{$\begin{array}{l}\text { レベル } \\
' 78\end{array}$} & \multirow{2}{*}{$\begin{array}{l}\text { 予測 } \\
{ }^{\prime} 79\end{array}$} & \multirow{2}{*}{$\begin{array}{l}\text { トレンド } \\
{ }^{\prime} 78 \rightarrow{ }^{\prime} 79\end{array}$} & \multicolumn{3}{|c|}{ デルファイ予測 } \\
\hline & & 1976 & 1977 & 1978 & & & & & 原 & 修正 & トレンド \\
\hline \multicolumn{12}{|c|}{ ルック イメージ (JAPAN)（数字はイメージ スコア） } \\
\hline 1 & ドレッシィな & 1.64 & 1.57 & 1.55 & & $L$ & 1.59 & $\sim$ & 2.02 & 1.51 & - \\
\hline 2 & 懐古的な & 1.33 & 1.44 & 1.61 & & $M$ & 1.73 & & 2.27 & 1.76 & \\
\hline 3 & フォーマルな & 1.49 & 1.36 & 1.28 & & $L$ & 1.38 & $\rightarrow$ & 2.06 & 1.55 & 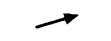 \\
\hline 4 & マニッシュな & 1.50 & 1.43 & 1.64 & & $M$ & 1.08 & & 2.36 & 1.85 & $\sim$ \\
\hline 5 & はなやかな & 1.40 & 1.47 & 1.47 & & $L$ & 1.51 & - & 1.55 & 1.04 & $\sim$ \\
\hline 6 & 個性的な & 1.75 & 2.08 & 2.08 & & $H$ & 2.07 & $\sim$ & 2.09 & 1.58 & $\rightarrow$ \\
\hline 7 & カジュアルな & 2.25 & 2.35 & 2.35 & & $H$ & 2.32 & $\sim$ & 2.64 & 2.13 & $\sim$ \\
\hline 8 & デコラティブな & 1.19 & 1.28 & 1.36 & & $L$ & 1.46 & $\rightarrow$ & 2.15 & 1.64 & $\sim$ \\
\hline 9 & フォークロア的 & 1.32 & 1.48 & 1.55 & & $M$ & 1.68 & - & 2.00 & 1.49 & $\sim$ \\
\hline 10 & 大人っぽい & 2.11 & 1.96 & 1.76 & & $M$ & 1.59 & $\rightarrow$ & 2.16 & 1.65 & $\sim$ \\
\hline 11 & ナチュラルな & 1.96 & 2.12 & 1.96 & & $M$ & 2.11 & $\rightarrow$ & 3.25 & 2.74 & - \\
\hline
\end{tabular}

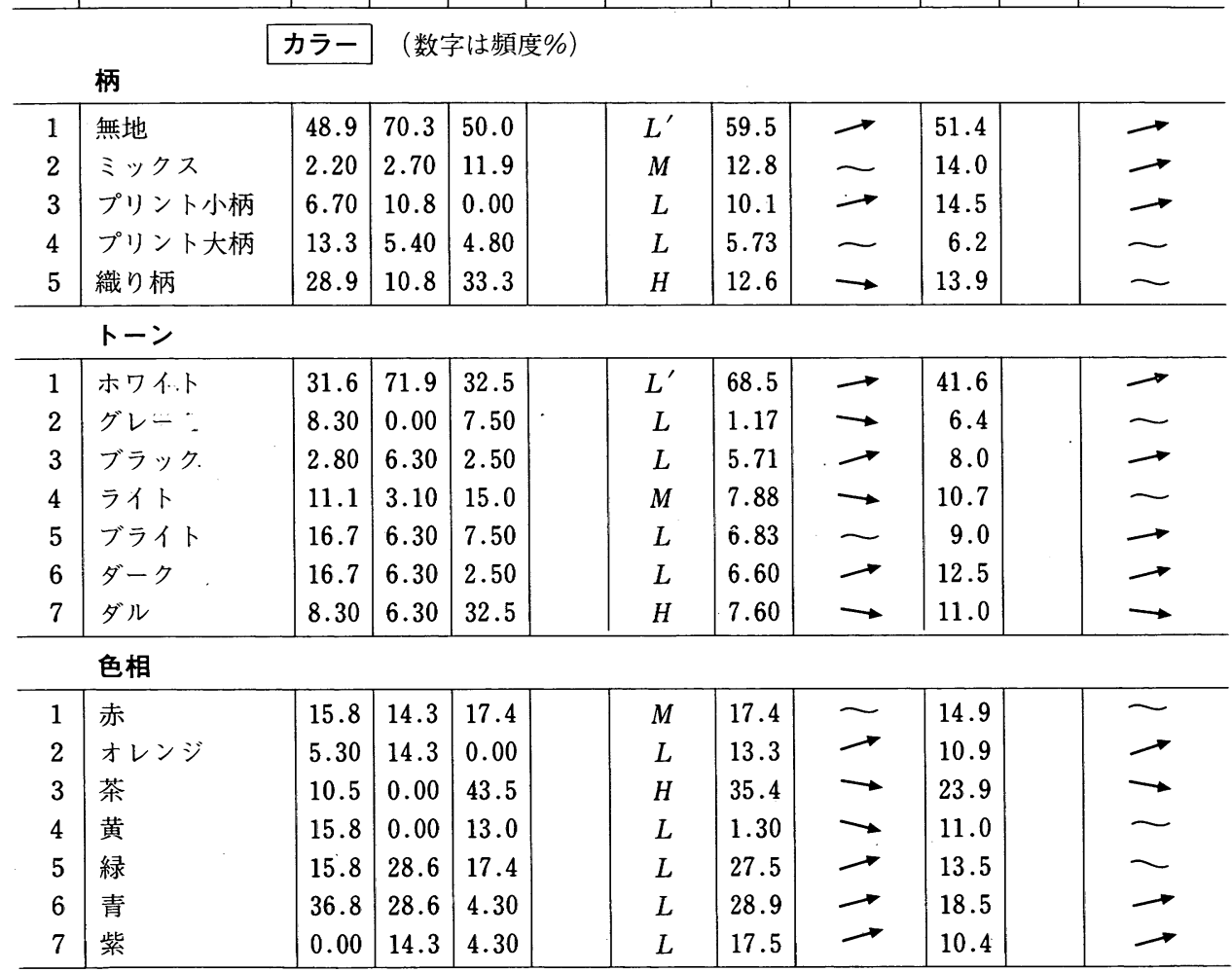

B. $\mathrm{K}-\mathrm{J}$ 法によるルック，素材の予測（直観的にルッ

ク，素材のチャンピオンを選ぶ）

$\mathrm{K}-\mathrm{J}$ 法は, 東工大川喜多二郎氏が開発した, 創造工学 の一種で, 複雑な現象, データを, 集団討議の中で直観 的に整理要約して, 問題点を抽出し, かつメンバの創造 的な発想を促しながら解决を導く方法である ${ }^{8)}$. ここで は，グループメンバがそれぞれ個人的な立場で，直観 的に乙れてそ来春のファッション アイテムとなると確 信するルック写真および素材サンプルを持ち寄り, グル 一プ討論によってサンプルの特徵を浮きぼりにし，かつ 似た者同士を集めて小さなクラスタとし, さらにクラス
表 6 予測手法の特性

\begin{tabular}{|c|c|c|}
\hline デー夕解析 & $\mathrm{K}-\mathrm{J}$ 法 & 感覚的推測 \\
\hline 解析の過程が煩雑 & 比較的容易 & 容易 \\
\hline $\begin{array}{l}\text { 推論の過程に専門 } \\
\text { 的経験不要 } \\
\end{array}$ & $\begin{array}{l}\text { 専門的経験, 熟練 } \\
\text { を要す }\end{array}$ & $\begin{array}{l}\text { 高度な専門的経験 } \\
\text { を要す }\end{array}$ \\
\hline $\begin{array}{l}\text { 結果に客観的, 論 } \\
\text { 理的な一貫性が得 } \\
\text { られる }\end{array}$ & $\begin{array}{l}\text { 直観的な推論と客 } \\
\text { 観的な体系化との } \\
\text { 混合 }\end{array}$ & $\begin{array}{l}\text { 主観的な結論, 論 } \\
\text { 理的な裏付けなし }\end{array}$ \\
\hline $\begin{array}{l}\text { トレンド, マクロ } \\
\text { な推定に適す }\end{array}$ & $\begin{array}{l}\text { マクロ, ミクロい } \\
\text { ずれにも適す }\end{array}$ & $\begin{array}{l}\text { マクロ, ミクロい } \\
\text { ずれにも適す }\end{array}$ \\
\hline $\begin{array}{l}\text { データの定型化, } \\
\text { 平均化の過程で生 } \\
\text { 々しさが失われる }\end{array}$ & $\begin{array}{l}\text { データの生々しさ } \\
\text { が保たれる }\end{array}$ & $\begin{array}{l}\text { データの生々しさ } \\
\text { が保て, 強調でき } \\
\text { る }\end{array}$ \\
\hline
\end{tabular}




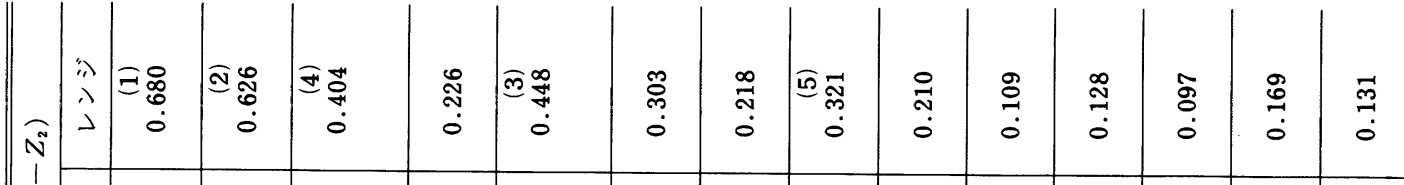

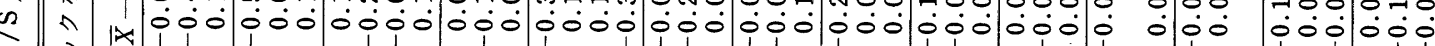

$\infty$

2

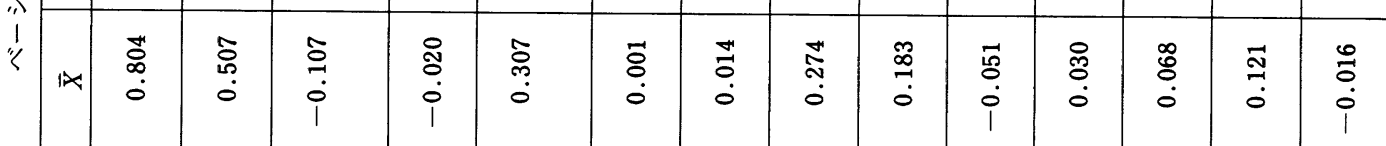

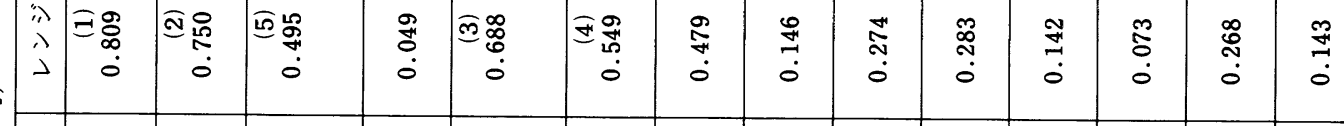

我

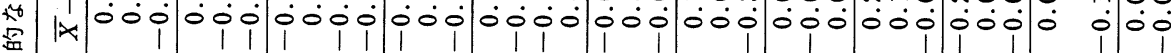

000000

.. 與

o

誌

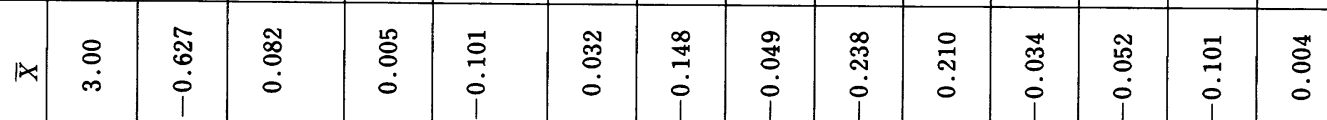

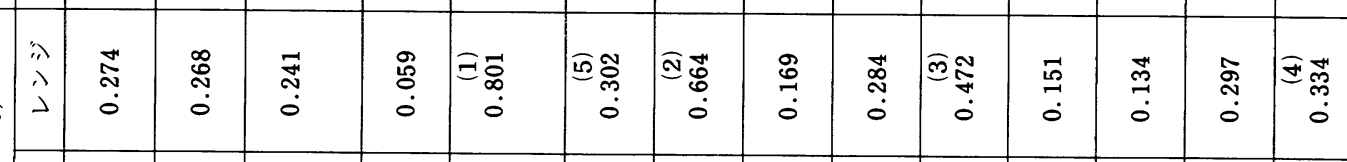

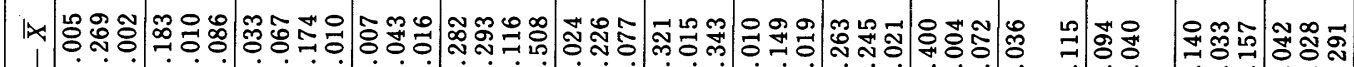

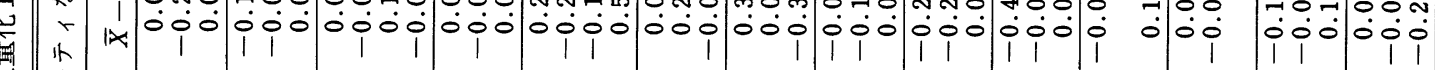

\begin{tabular}{|c|c|c|c|c|c|c|c|c|c|c|c|c|c|c|c|}
\hline $\begin{array}{l}\text { 奖 } \\
\text { אר }\end{array}$ & $|x|$ & ஜ্ণ & \begin{tabular}{l}
$\mathscr{\infty}$ \\
\hdashline \\
0
\end{tabular} & ஜ్లి & $\begin{array}{l}\hat{8} \\
\dot{0}\end{array}$ & $\begin{array}{l}\text { o } \\
\stackrel{\infty}{~} \\
0\end{array}$ & $\begin{array}{l}\text { ¿े } \\
\dot{0}\end{array}$ & $\begin{array}{l}\overrightarrow{\tilde{N}} \\
\dot{j}\end{array}$ & $\begin{array}{l}0 \\
0 \\
0\end{array}$ & $\begin{array}{l}\stackrel{?}{0} \\
\stackrel{0}{0}\end{array}$ & $\begin{array}{l}\stackrel{8}{+} \\
\stackrel{0}{0}\end{array}$ & $\begin{array}{l}\mathscr{\%} \\
\dot{0} \\
\dot{0}\end{array}$ & $\begin{array}{l}\text { ठ̆ } \\
\dot{0} \\
\dot{1}\end{array}$ & $\begin{array}{l}\stackrel{0}{1} \\
\stackrel{0}{0}\end{array}$ & $\begin{array}{l}\text { Yै } \\
\dot{0}\end{array}$ \\
\hline
\end{tabular}

\begin{tabular}{|c|c|c|c|c|c|c|c|c|c|c|c|c|c|}
\hline i) & $\begin{array}{l}\text { กี } \\
\stackrel{0}{0}\end{array}$ & 总 & $\stackrel{0}{=}$ & $\begin{array}{l}\hat{\delta} \\
0 \\
0\end{array}$ & త్ & 跑 & 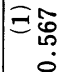 & $\vec{\exists}$ & $\underset{\overparen{7}}{\stackrel{2}{0}}$ & న్రঙ্ণু & $\underset{J}{\sharp}$ & $\stackrel{\mathscr{8}}{\sharp}$ & ஓ্. \\
\hline
\end{tabular}

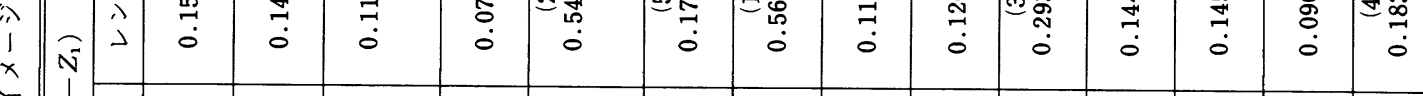

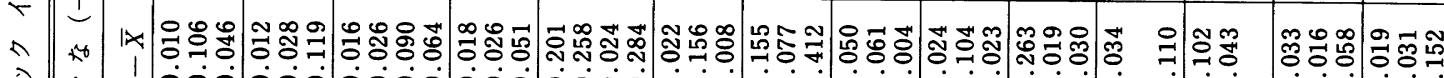

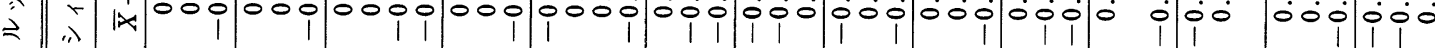

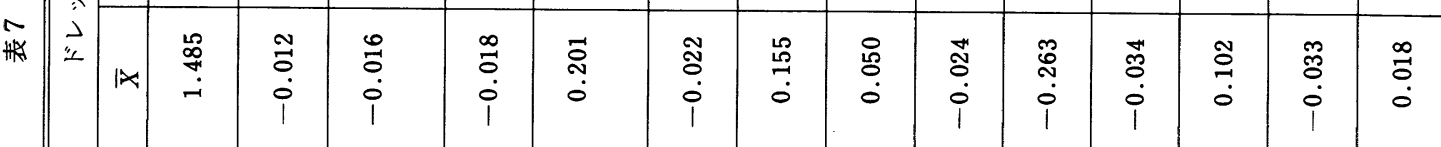

\begin{tabular}{|c|c|c|c|c|c|c|c|c|c|c|c|c|c|c|}
\hline & 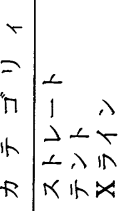 & $\mid \begin{array}{lll}x & \overrightarrow{2} & 5 \\
\therefore & 1 & 1 \\
y & 1 & x\end{array}$ & 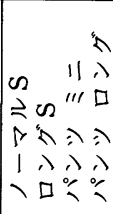 & 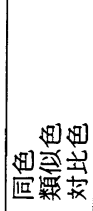 & 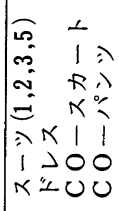 & 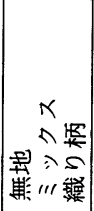 & 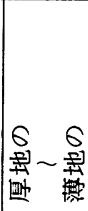 & 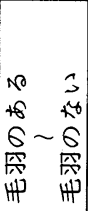 & $\left|\begin{array}{cc}0 & 3 \\
+8 & +6 \\
6 & -6 \\
f & + \\
\lambda & \lambda\end{array}\right|$ & 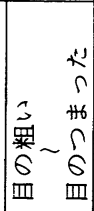 & 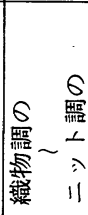 & 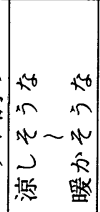 & 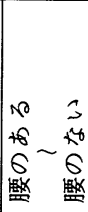 & 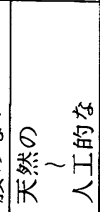 \\
\hline & 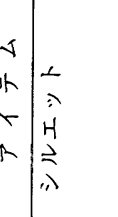 & $\begin{array}{l}\dot{1} \\
\dot{r} \\
r\end{array}$ & 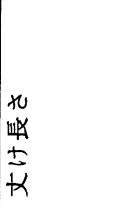 & | & 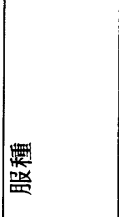 & 努 & $\begin{array}{l}3 \\
1 \\
x \\
\vdots \\
5 \\
\vdots\end{array}$ & & & & & & & \\
\hline
\end{tabular}


夕相互を比較検討するととによって，全体の配 置を整 え，マップを構成した. 同時に各サンプルに番号を付 け，全員投票によって，ルック，素材候補の中から数点 のチ+ンピオンを選び, 直観的な判断による来シーズン のファッション アイテムとした，参考までにデータ解 析，K-J 法およびてれまで行われている企画スタッフに よる感覚的推測の特徴をまとめれば表 6 のようになる.

C.ルックイメージと服装要因の関係

最後に林の数量化 I の方法" ${ }^{9}$ によって, ルックイメ ージを服装要因の関係を定量的にまとめる. 林の数量 化 I の方法は，質的な变数を含む重回帰分析の一種で あり, こてではシルエット,フィットなどのアイテム〜 カテゴリィに与えられた変量の和で, ルックイメージ スコアを近似させる方法である. 表 7 は得られた結果の 一部を示す. ての表で, あるルックサンプルのイメー ジスコア（例えばドレッシィな）は，そのルックを構 成するアイテム〜カテゴリィに与えられたスコア $X_{i}$ の 和（例えばストレートなシルエットでビッグ ルックの 場合は， $1.485+0.010-0.012+0.012=1.585)$ で与え られる.また各列のレンジはあるアイテムについてカテ ゴリィが異なるととによる最大〜最小值の差を意味する から，服装要因アイテムの中でどれがイメージを左右す るかは、レンジの大きさを比べればよい、レンジ欄に注 記されている（数字）はそれぞれのイメージを左右する 度合のランキングを示している。例えば，ドレッシィな イメージを左右する要因の第 1 は素材の厚地〜薄地であ り，服種要因がそ机次ぐてとがわかる.ドレッシィ イメージの反対極にあるスポーティイメージは, 当然 のととながら，ドレッシィイメージを左右する要因が
ちょうど反対方向に作用しているととも明らかであろ う.またルック イメージを左右する影響度の大きなア イテムは、イメージによって異なることも示されてい る.例えば個性的〜ベーシックなイメージは，シルエッ トとフィットによって最む大きく左右され，第 1 主成分 イメージと異なる様相を示している.

D. 予測のまとめ

以上のようにいろいろな方法,ルートをたどって得ら れた次シーズンの予測結果は，必ずしも完全に一致して いない. しかし、ルック イメージを中心として要約す れば，図8が示すように，次シーズンに期待されるルッ ク（ファッション）が具備すべき（必要）条件がおのず から明らかとなろう．乙の図は，第 1 ，第 2 主成分の主 なイメージを中心の綐軸に，横軸にルックイメージに 寄与する服装要因を影響度の大小に従って矢印で結んだ あので, 四中の矢印はそれぞれ，要因でとに見た次年度 へのトレンドを表 5 から転記している。こてでは図示し 得ないが，ての 2 軸を直交させて平面を構成し， $\mathrm{K}-\mathrm{J}$ 法 その他の方法で得られた期待ルックのサンプルの中か ら, このフロー シート要件をみたすルックを選び, イメ ージ空間における妥当な位置に貼り付ければ, データ予 測と直観的な予測が一つのマップにまとめられたととに なる。

\section{5. おわりに}

ファッション（現象, 商品）は, つきつめれば, 個々 の消費者の好みや主観的な価值評価依存していること は明らかであり，他方客観的な対象として捉えようとす れば, 普及率, 伸び率などで数量化できるととも確かで

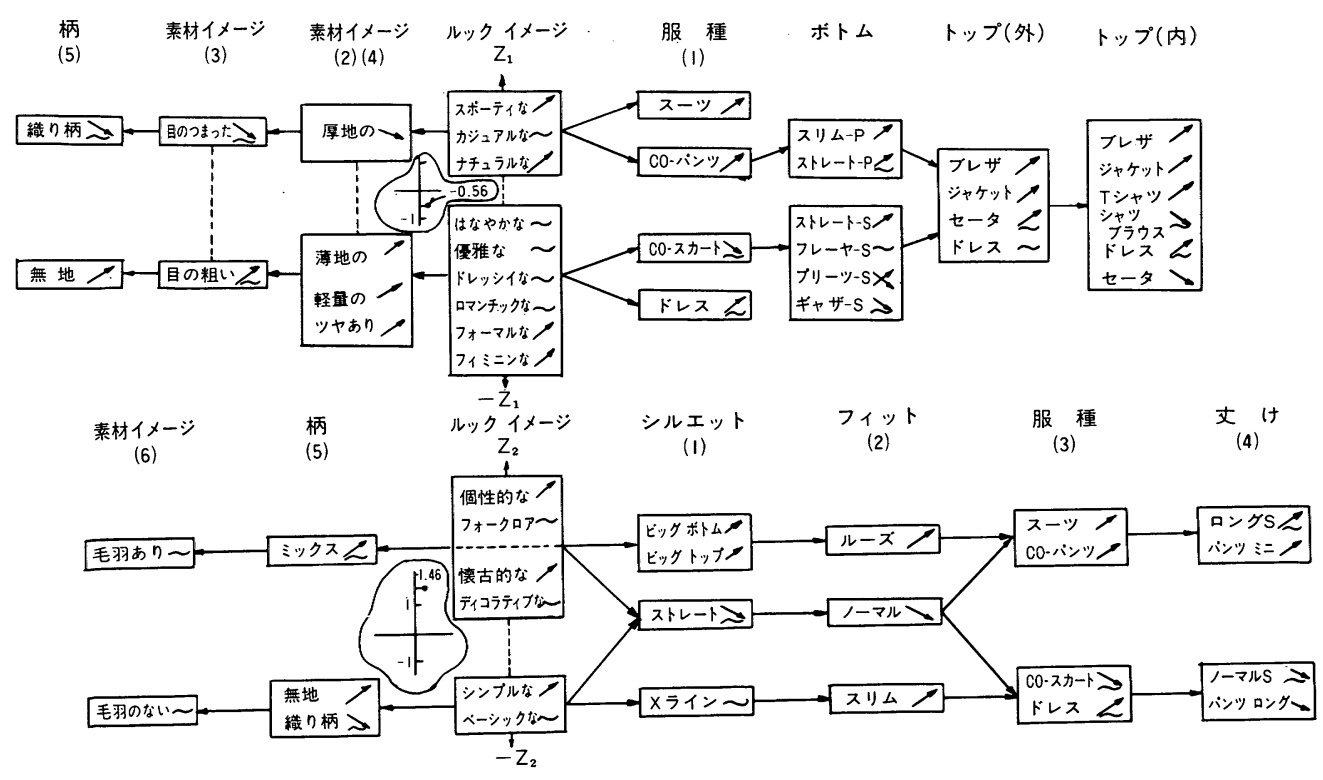

図 879 年 S/S 予測のまとめ (注 : CO-: コーディネートの意) 
ある.とこでは，着こなし（ルック）〜ルックイメー ジ〜時系列的な変化〜仮説の導入〜予測, というプロセ スに従って次シーズンのファッション予測を行い, さら に別のルートからの感覚的な予測との融合を試みた. と れらの試みは, 各社のデザイナ, 企画スタッフ, エンジ ニアのグループ作業によって実現したが，表 6 でも例示 したようにファッションを追求する限りは, 感覚的なア プローチと，エンジニアリング アプローチは不可欠で あり，また多角的なアプローチによって始めて可能とな る. この小文の目的も同様な試みを他に期待してのとと にほかならない。

なお，本稿は1978年 5 月17日，本学会の「人間の心理 と被服一被服科学基礎講座(第3次)」において発表した 内容 ${ }^{10)}$ を心にまとめたものである.

注

ファッンョンテクノロジィグループ (F. T. G.)，1977年 2 月に発足. ファッン・ョン情報の分析, 予測, 商品企画について 20回の討議, 作業を続け，現在に至っている、メンバは， 旭化成工業(俶)マーケティング部 (侏)旭化成テキスタイル・婦人児服事業部 岩仲毛織株式会社 岩仲ニット株式会社
多田敦子（デザイナ）

蝶理(㑣) 繊維マーケティング部

東海染工株式会社・ロビュ一事業部

富地正招（テキスタイルエンジニア）

浜産製織株式会社

(柣ワールド・企画本部

\section{文献}

1) 川崎; 緎機誌, 31，P25 (1978-1)

2) 清水; 生命を捉えな扣す, P49 (1978-5), 中公新書

3) 旭化成工羓(㹯)レディスカジュアル委員会資料；WHAT'S WANTED! (1978)

4) 供えば，奥野ほか；多変量解析法（1971-10)，日科技連

5）例えば，宮本；商品の流行学 (1976.1)，ダイヤモンド社

6) J. A. シャャーナウ他（尾原訳）；ファッンョンビジスの 世界, p. 7 (1968), 東洋経済

7）例えば，只野ほか；ソフトテクノロジー，P112 (1972)， 丸善

8) 例えば，川喜多；発想法 (1967), 中公新書

9)例えば，林，村山；市場調査の計画と実際 (1964.8), 日 刊工業新聞社

10）川崎；ファッションテクノロジーと消費動向，「人間の心 理と被服一被服科学基礎講座（第 3 次）」テキスト (1978. 5.17)，日本織維機械学会

\section{繊維機器総目録(国産機) -1978年版一}

\section{Japanese Textile Machinery Guide'78}

日本の新鋭繊維機器 510 機種を分野別に整理し，掲載した。とくに，それぞれの機器の 名称・特長は和文と英文で，仕様は英文でというように，本書が国内だけでなく，海外で も多く使用されることを考慮し編集した．また，目次，索引等を充実させ，本書の多角的 な用途に対応できるよう配慮してある。

B 6 判(ハンディタイプ), 約330頁

定価 2500 円，送料200円

発行・発売 $\bar{\top} 550 /$ 大阪市西区勒本町1-8-4 (大阪科学技術センタービル) 日本繊維機械学会 